\title{
Near-toe amputation from prolonged compression stocking use
}

\author{
Victoria Ward, Ben Lovell
}

Department of Acute Medicine, University College London Hospitals NHS Foundation Trust, London, UK

\section{Correspondence to} Dr Victoria Ward,

victoria.ward@doctors.org.uk

Accepted 17 June 2017

\section{DESCRIPTION}

A 73-year-old man was referred to the acute medical team by his general practitioner with a suspected diabetic footinfection. He had a background of type 2 diabetes mellitus, chronic venous insufficiency and ulcers, peripheral vascular disease and deep venous thromboses (DVT).

The patient revealed that he had not removed his compression stockings for 4 months. He had chronic venous changes bilaterally, a swollen, erythematous right leg and foul-smelling discharge from his right foot with a deep wound at the base of his fourth toe due to compression by the distal edge of the stocking, with partial amputation of this digit (figure 1).

X-ray of his foot (figure 2) showed bone destruction of the right fourth toe in keeping with osteomyelitis. Venous Doppler scans showed acute and chronic thrombi in the distal deep veins. Arterial Dopplers demonstrated severe arterial disease in superficial and deep vessels. He was transferred to the vascular department for further care who arranged outpatient CT angiogram.

Compression stockings are used to prevent recurrence of venous disease and lymphoedema,

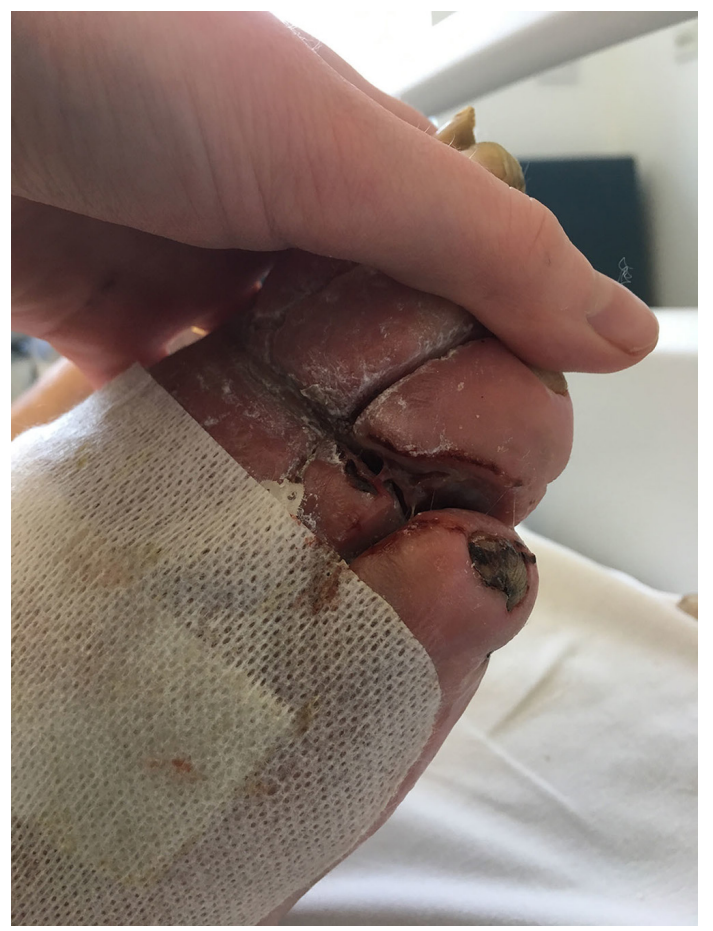

Figure 1 Photograph of patient's right foot showing near amputation of fourth toe.

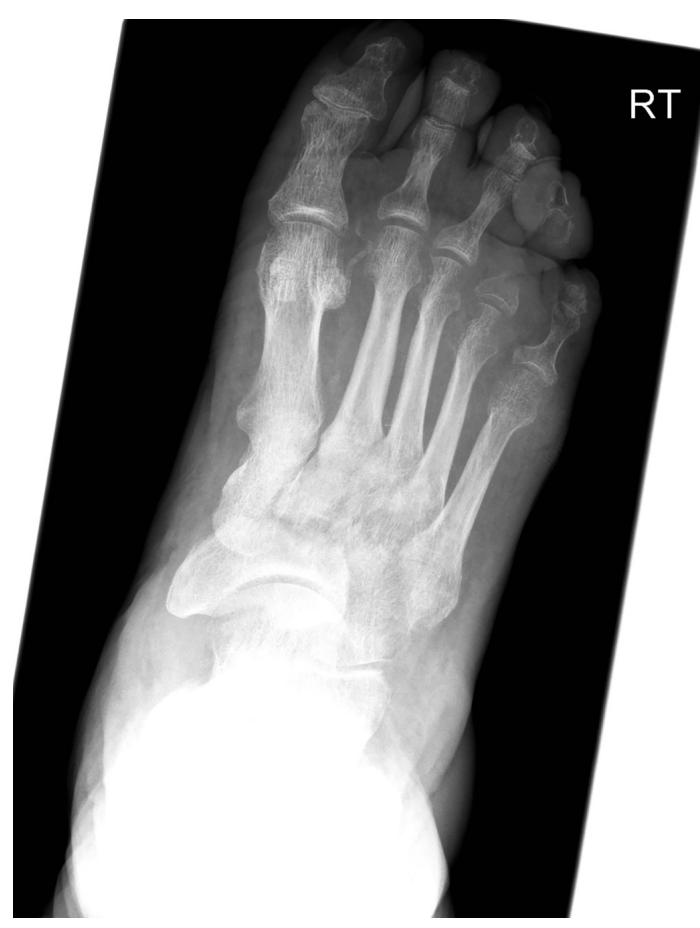

Figure 2 Plain film X-ray of patient's right foot showing bone destruction of fourth toe in keeping with osteomyelitis.

to prevent post-thrombotic syndrome or recurrence of DVT. NICE (National Institute for Health and Care Excellence) guidelines advise that stockings should be taken off at bedtime and, where not possible, could be extended to a maximum duration of 7 days. ${ }^{1}$ Stockings should not be used in patients with significant arterial disease due to the risk of limb ischaemia and necrosis. This case highlights the sequelae of poorly fitting compression stockings that have not been removed regularly, and their use in patients with significant arterial disease.

Learning points

- Assess presence and severity of arterial disease before prescribing compression stockings.

- Ensure correct fitting of compression stockings.

- Educate patient on how to manage compression stockings and the duration of wear. 
Contributors Report written by VW and edited and overseen by BL.

Competing interests None declared.

Patient consent Obtained.

Provenance and peer review Not commissioned; externally peer reviewed.
(C) BMJ Publishing Group Ltd (unless otherwise stated in the text of the article) 2017. All rights reserved. No commercial use is permitted unless otherwise expressly granted.

\section{REFERENCES}

1 National Institute for Health and Care Excellence. 2012. Clinical Knowledge Summaries: Compression Stockings

Copyright 2017 BMJ Publishing Group. All rights reserved. For permission to reuse any of this content visit http://group.bmj.com/group/rights-licensing/permissions.

BMJ Case Report Fellows may re-use this article for personal use and teaching without any further permission.

Become a Fellow of BMJ Case Reports today and you can:

- Submit as many cases as you like

- Enjoy fast sympathetic peer review and rapid publication of accepted articles

- Access all the published articles

- Re-use any of the published material for personal use and teaching without further permission

For information on Institutional Fellowships contact consortiasales@bmjgroup.com

Visit casereports.bmj.com for more articles like this and to become a Fellow 